\title{
THE INFLUENCE OF GYPSUM TREATMENT ON PHOSPHORUS RETENTION IN BOTTOM SEDIMENTS AND ON THE WATER OF MAN-MADE LAKE
}

\author{
Lilianna Bartoszek' \\ 1 Department of Environmental and Chemistry Engineering, Rzeszów University of Technology, al. Powstańców \\ Warszawy 12, 35-959 Rzeszów, Poland, e-mail: bartom@prz.edu.pl
}

Received: 2016.10.15

Accepted: 2016.11.16

Published: 2017.01.01

\begin{abstract}
The paper presents a research covering the stability of phosphorus retention in the bottom sediments, resulting from application of gypsum in anoxic conditions and in slightly acidic environment $(\mathrm{pH} \sim 5)$ of solutions. The present work also contains an analysis of possible effects of gypsum application for water from the reservoir, on the basis of selected parameters of overlying water. Undisturbed deposit cores extracted from two research stations on the Solina Reservoir have been a subject to a 10 -weeks long exposure in determinate conditions, after application of gypsum. The conducted research indicated that retention capacities of deposits, which become increased after the use of gypsum, will decrease over time (e.g. after winter period). Application of gypsum led to a quite significant increase in concentrations of calcium in solutions. Intense release of iron from the sediments into the solutions and decrease in $\mathrm{SO}_{4}^{2-}$ content, during the said 10-week exposure in anoxic conditions, indicates the use of iron (III) and sulphates as electron acceptors in process of oxidization of an organic substance.
\end{abstract}

Keywords: reservoirs, bottom sediments, treatment of gypsum, stability of phosphorus retention

\section{INTRODUCTION}

Biogenic substances which reach the reservoirs, coming from external sources are used by the aquatic organisms and after the vegetation period, together with their dead remains, they deposit to the bottom sediments. Phosphorus compounds may also react with other substances present in water and precipitate directly into the deposits in the form of sparingly soluble inorganic or organic-inorganic compounds [Bajkiewicz - Grabowska 2002, Zbierska et al. 2016]. Various transformations take place in bottom sediments, including decomposition of organic matter, as a result of which soluble forms of nitrogen and phosphorus may be released into the water [Gruca-Rokosz el al. 2009, 2011]. Stability of phosphorus deposition in bottom sediments depends on compounds in which it occurs, oxygen conditions, temperature, $\mathrm{pH}$, presence of ele- ments which increase its retention in the deposits [Bartoszek and Koszelnik 2016].

Calcium is also one of the elements with which phosphorus creates sparingly soluble compounds in aquatic environment apart from iron, aluminium and manganese. Depending on concentration of calcium and phosphates in water and depending on conditions present in the water, phosphorus may precipitate directly in the form of calcium phosphates, be adsorbed on the surface of calcium carbonate particles, and may also co-precipitate with calcium carbonate [Berg et al. 2004, Lin and Singer 2006, Sø et al. 2011, Liu et al. 2012]. Effectiveness of calcium compounds in comparison to aluminium and iron compounds in retaining phosphorus in bottom sediments is weaker, but they are less harmful to the aquatic environment [Prepas et al. 2001a, 2001b, Zhang et al. 2001]. The research conducted in ex situ conditions on undisturbed deposit cores of the 
Solina and Myczkowce Reservoirs indicated that addition of dihydrate calcium sulphate (gypsum) to bottom sediments significantly impacts on the increase in phosphorus retention. With the exception of sandy littoral deposits, gypsum application resulted in a complete removal of phosphorus from solutions by deposits subject to resuspension [Bartoszek and Tomaszek 2010].

The aim of the present paper was to verify the stability of growth of phosphorus retention in bottom sediments, as a result of gypsum application in anoxic conditions and decreased $\mathrm{pH}$ of solutions. The present work also contains an analysis of possible effects of gypsum application for water from the reservoir, on the basis of selected parameters of overlying water.

\section{RESEARCH AREA AND METHODOLOGY}

The Solina Reservoir is the deepest and the largest artificial lake in Poland in terms of capacity (Table 1). Together with the smaller Myczkowce Reservoir situated beneath, it is used for hydropower purposes. Its mountainous, pasture-forest catchment area is scarcely populated and not much developed. Due to adverse landform features and unordered water and sewage management, especially within the direct catchment area, the object is considerably exposed to degradation [Koszelnik et al. 2002, Bartoszek and Czech 2014].

As part of the research, undisturbed deposit cores were extracted and placed in 6 perspex tubes $(0-5 \mathrm{~cm}$ layer) in October 2007, with the use of a tubular sampler, at two research stations on the Solina Reservoir: 1. Centralny, 2. Skałki (average depth approx. 45, $15 \mathrm{~m}$ respectively) (Fig. 1).

The pipes were being closed at the bottom with the use of a silicone cap. At the same time the water was taken from the reservoir, and after being thinned with distilled water it was used to prepare the solutions. In order to achieve anoxic conditions, the solutions were deoxidized after preparation with the use of anhydrous sodium sulphate (IV) [Wiśniewski 1995, 2006]. After application of gypsum in the amount of 300 and $500 \mathrm{mg}$, reactors with undisturbed sedi- ment cores were filled with prepared solutions, and the sediments were subject to 10-minute resuspension through stirring of approx. $1 \mathrm{~cm}$ surface layer using a mechanical stirring device (RPM approx. 150 revolutions per minute). Approximately $12.6 \mathrm{~cm}^{3}$ of deposit in $314 \mathrm{~cm}^{3}$ of solution was subject to resuspension. All of the reactors were filled with solutions containing the same concentration of phosphate phosphorus 1.9 $\mathrm{mgP} \mathrm{dm}{ }^{-3}(\mathrm{Cp})$. Some of them were deoxidized, in case of some natural oxygen content was left within them, but with $\mathrm{pH}$ decreased down to 5 . After the resuspension procedure was finished, the reactors were left in a cool, dark place (in the temperature of approx. $15^{\circ} \mathrm{C}$ ) for the period of approx. 10 weeks. This time period was selected due to the fact that it corresponds to the approximate ice cover period on the lakes in the temperate transitional climate [Wiśniewski 1995]. The reactors with the sediments exposed in anoxic conditions were closed with plastic plugs and tightly wrapped in Parafilm. Solutions with decreased $\mathrm{pH}$ were carefully aerated using aquarium pumps for approx. $2 \mathrm{~h}$ daily and the reactors were closed with Parafilm. The $\mathrm{pH}$ value was monitored every 2 days and adjusted it accordingly. At the same time, the control samples with no gypsum within them were exposed in the same conditions and for the same period. After 10 weeks the supernatant solution was leveraged to measuring cylinders. Within the solutions, concentrations of mineral phosphorus, iron, calcium and sulphates were determined. Phosphates (reaction with ammonium molybdate), iron (reaction with phenanthroline) and sulphates (reaction with barium iodate and tannin) were determined spectrophotometrically (Aquamate Thermo Spectronic). Concentration of calcium was determined with the application of the titrimetric method with EDTA. Sediment cores recovered after exposure in anoxic conditions were exposed for the second time to the newly prepared deoxidized solution with $\mathrm{P}_{-} \mathrm{PO}_{4}{ }^{3-}$ concentration of $1.9 \mathrm{mgP} \mathrm{dm}{ }^{-3}$, and without repeated gypsum application underwent resuspension and resedimentation. After two hours exposure in anoxic conditions, within

Table 1. Morphometric parameters of the Solina Reservoir

\begin{tabular}{|c|c|c|c|c|c|}
\hline Parameter & Area & $\begin{array}{c}\text { Average (max.) } \\
\text { depth }\end{array}$ & $\begin{array}{c}\text { Maximum } \\
\text { volume }\end{array}$ & Catchment area & Water retention time \\
\hline Reservoir & {$\left[\mathrm{km}^{2}\right]$} & {$[\mathrm{m}]$} & {$\left[\mathrm{M} \mathrm{m}^{3}\right]$} & {$\left[\mathrm{km}^{2}\right]$} & {$[\mathrm{d}]$} \\
\hline Solina & 22 & $22(60)$ & 500 & 1174 & 214 \\
\hline
\end{tabular}




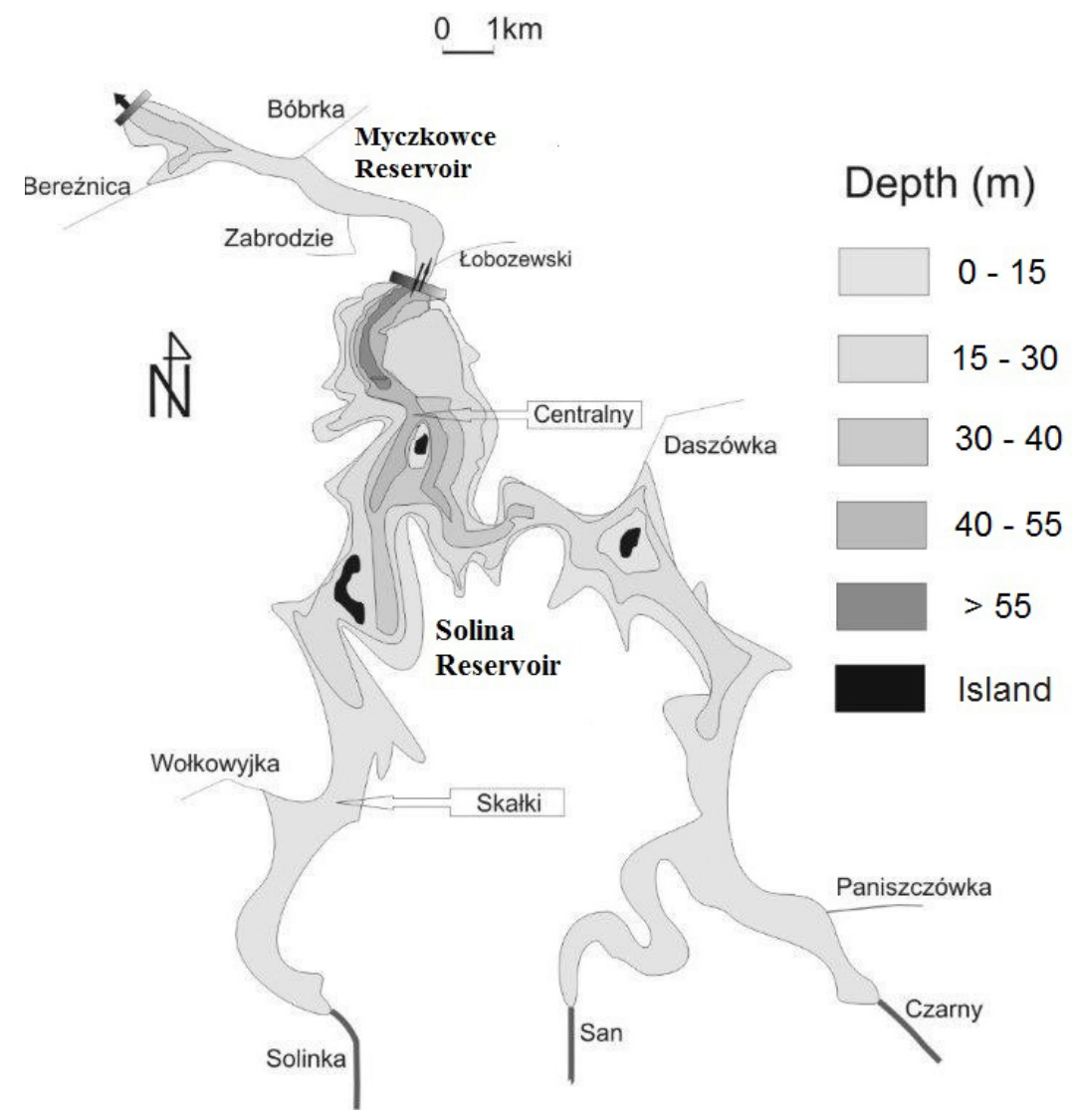

Figure 1. Localisation of the sediment sampling points in the Solina Reservoir

the leveraged solutions, phosphate phosphorus content was being determined. Further analysis used $1 \mathrm{~cm}$ top layer of the sediment cores. The sediments, after drying and thorough grinding, were mineralized and phosphorus was fractioned. As a result of phosphorus fractionation with the use of the SMT method, the fractions of NAIP (non-apatite, inorganic phosphorus i.e. compounds with $\mathrm{Fe}, \mathrm{Al}, \mathrm{Mn}$ ), AP (apatite phosphorus i.e. compounds with $\mathrm{Ca}$ ) and $\mathrm{OP}$ (organic phosphorus) were obtained [Bartoszek 2008]. After microwave mineralization of the deposits in concentrated $\mathrm{HNO}_{3}(2-4.5 \mathrm{MPa}$ - UniClever II Plazmatronika), the phosphorus content in achieved mineralisates was determined.

The content of dissolved oxygen, $\mathrm{pH}$ and selectively the redox potential in solutions before and after the exposures in given experimental conditions, using the MultiLine P4 multiparameter gauge (WTW Germany) with CellOx 325 oxygen probe (oxygen $-\mathrm{O}_{2}$ ), Sen Tix 61 combined electrode $(\mathrm{pH})$ and Sen Tix ORP combined electrode (redox potential - Eh) were also measured.

\section{RESULTS AND DISCUSSION}

Phosphorus retention after 10-week ex situ exposure in anoxic conditions and in slightly acidic environment of solutions

After 10-week exposure of deposits in a slightly acidic environment $(\mathrm{pH} \sim 5)$ in control samples, phosphorus retention at the level of 99.3\% and 99.8\% (Centralny; Skałki respectively) was observed (Table 2.). Samples with 300 and $500 \mathrm{mg}$ doses of gypsum were characterized by similar retention from $99.7 \%$ to $100.0 \%$. Thus, no significant differences were found regarding the phosphorus retention phenomenon within the samples with and without gypsum. Research conducted in the years 2005-2006 indicated that sediments of the Solina Reservoir are characterized by high content of iron, aluminium, manganese and relatively low content of organic matter, phosphorus and calcium [Bartoszek et al. 2015]. In deposits in which the retention capacity of this element results mainly from creation of compounds with 
Table 2. Phosphorus retention [\%] in the bottom sediments after 10 weeks of ex situ exposure in the conditions of decreased $\mathrm{pH}$, and 10 weeks (I) and $2 \mathrm{~h}$ (II) of exposures in anoxic conditions

\begin{tabular}{|c|c|c|c|}
\hline \multirow{2}{*}{$\begin{array}{l}\text { Dosage } \\
\text { gypsum }\end{array}$} & \multirow{2}{*}{$\begin{array}{c}\mathrm{pH} \sim 5 \\
\text { Retention } \\
\mathrm{P}_{-} \mathrm{PO}_{4}{ }^{3-}\end{array}$} & \multicolumn{2}{|c|}{ Anoxic } \\
\hline & & $\begin{array}{c}\text { Retention I } \\
\mathrm{P}_{-} \mathrm{PO}_{4}{ }^{3-}\end{array}$ & 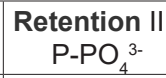 \\
\hline [mg] & [\%] & [\%] & [\%] \\
\hline \multicolumn{4}{|c|}{ Centralny } \\
\hline- & 99.3 & 96.0 & 61.4 \\
\hline 300 & 99.7 & 99.6 & 62.8 \\
\hline 500 & 100.0 & 99.9 & 72.3 \\
\hline \multicolumn{4}{|c|}{ Skatki } \\
\hline- & 99.8 & 90.6 & 35.1 \\
\hline 300 & 99.8 & 92.2 & 38.5 \\
\hline 500 & 99.9 & 96.3 & 52.8 \\
\hline
\end{tabular}

iron (III), decrease of the $\mathrm{pH}$ value may cause an intense flow of phosphorus towards the deposits, while in deposits with high calcium content the decrease of $\mathrm{pH}$ may initiate its release into the water [Bajkiewicz-Grabowska 2002]. According to Lossow and Gawrońska [2000], optimal $\mathrm{pH}$ level for removal of phosphorus from water using iron coagulant containing iron III is $4.5-5$.

After 10-week exposure of sediments in anoxic conditions, retention in control samples at the level of $96.0 \%$ and $90.6 \%$ (Centralny; Skałki respectively) was observed (Table 2). In samples with gypsum, retention occurred at the level of $99.6 \%$ and $99.9 \%(300 ; 500 \mathrm{mg}$ doses respectively) within the sediments from the Centralny station and $92.2 \%$ and $96.3 \%$ (300; $500 \mathrm{mg}$ doses respectively) within the sediments from the Skałki station. Two hour exposure of the same sediment cores conducted for the second time in anoxic conditions, using newly prepared solutions with phosphate phosphorus concentration of $1.9 \mathrm{mgP} \mathrm{dm}^{-3}$, but without second gypsum application, did not confirm preservation of retention capacities of the sediments at the same level. In the case of the sediments from the Centralny station (in spite of previously retained phosphorus portions) $61.4 \%$ retention in the control sample was only slightly lower than $68.3 \%$ observed in previous research during 2 h exposure (Table 3) [Bartoszek and Tomaszek 2010]. However, the natural retention capacity of sediments from the Skałki station weakened significantly. The deposits from this station retained only $35.1 \%$ of subsequent phosphorus portion, whereas directly after $2 \mathrm{~h}$ exposure in anoxic conditions retention at the level of $61.7 \%$ was achieved. The sediments to which dihydrate calcium sulphate (VI) was applied 10 weeks earlier indicated retention at the level of $62.8 \%$ and $72.2 \%$ (Centralny) as well as $38.5 \%$ and $52.8 \%$ (Skałki). The impact of gypsum on phosphorus retention in deposit after 10-week exposure in anoxic conditions was insignificant (Table 2). In relation to the control sample, only up to $10 \%$ more phosphorus became retained in deposits from the Centralny station. Deposits from the Skałki station retained slightly more phosphorus, approx. $18 \%$.

Analysis of phosphorus fractionation in the sediments left after the experiment indicated a slight increase in the AP fraction content in deposits with added dihydrate calcium sulphate (VI) $(3.2-11.8 \%)$, in relation to deposits of control samples in slightly acidic environment (Table 4). In deposits exposed in anoxic conditions, the observed changes in AP fraction content were similar (at the level of 4.5-12.6\%). The NAIP fraction content would vary very irregularly, often alternately indicating a slight upward and downward trend. In the sediments from the Skałki station, after exposure in both experimental conditions, slight decrease in content of OP was noticed.

Due to long time of value stabilization, measurement of redox potential (Eh) was conducted for deoxidized initial solutions as well as for selected solutions after 10-week exposure (Table 5). The concentration of $\mathrm{O}_{2}$, which, in deoxidized initial solutions, fluctuated between 0.01 and 0.03 $\mathrm{mgO}_{2} \mathrm{dm}^{-3}$, after 10 -weeks the respective values amounted between 0.08 and $0.15 \mathrm{mgO}_{2} \mathrm{dm}^{-3}$ was monitored (Table 5). The observed decrease of $\mathrm{pH}$ in the solutions after 10 -week exposure in anoxic condition was probably caused by creation of weak organic acids and $\mathrm{CO}_{2}$ during decomposition of organic matter.

Table 3. Phosphorus retention [\%] in the bottom sediments under the influence of gypsum after $2 \mathrm{~h}$ of ex situ exposure in anoxic conditions [Bartoszek and Tomaszek 2010]

\begin{tabular}{|c|c|c|}
\hline \multirow{2}{*}{$\begin{array}{l}\text { Initial concentration } \\
\mathrm{P}^{2} \mathrm{PO}_{4}{ }^{3-} \text { in solution } \mathrm{Cp}=\end{array}$} & \multicolumn{2}{|c|}{ Anoxic } \\
\cline { 2 - 3 } & \multicolumn{2}{|c|}{ Retention $\mathrm{P}_{-} \mathrm{PO}_{4}{ }_{4}^{3-}[\%]$} \\
\hline Dosage gypsum [mg] & Centralny & Skałki \\
\hline- & 68.3 & 61.7 \\
\hline 200 & 99.8 & 98.6 \\
\hline 300 & 99.9 & 99.9 \\
\hline 400 & 99.5 & 99.8 \\
\hline
\end{tabular}


Table 4. The contents of the total phosphorus $\left(\mathrm{P}_{\text {tot. }}\right)$ and its fractions in sediments after 10 weeks of exposure in anoxic and decreased $\mathrm{pH}$ conditions

\begin{tabular}{|c|c|c|c|c|c|c|c|c|}
\hline $\begin{array}{l}\text { Dosage } \\
\text { gypsum }\end{array}$ & \multirow{2}{*}{ Conditions } & $P_{\text {tot.. }}$ & \multicolumn{2}{|c|}{ NAIP } & \multicolumn{2}{|c|}{ AP } & \multicolumn{2}{|c|}{ OP } \\
\hline [mg] & & $\begin{array}{l}\text { [mg g } \\
\text { of d.w.] }\end{array}$ & $\begin{array}{l}\text { [mg g } \\
\text { of d.w.] }\end{array}$ & {$[\%]$} & $\begin{array}{l}\text { [mg g } \\
\text { of d.w.] }\end{array}$ & {$[\%]$} & $\begin{array}{l}\text { [mg g-1 } \\
\text { of d.w.] }\end{array}$ & [\%] \\
\hline & \multirow{4}{*}{$\mathrm{pH} \sim 5$} & \multicolumn{7}{|c|}{ Centralny } \\
\hline- & & 0.943 & 0.255 & 27.0 & 0.373 & 39.5 & 0.305 & 32.3 \\
\hline 300 & & 0.983 & 0.265 & 27.0 & 0.385 & 39.2 & 0.315 & 32.1 \\
\hline 500 & & 0.965 & 0.251 & 26.0 & 0.417 & 43.2 & 0.302 & 31.3 \\
\hline- & \multirow{3}{*}{ anoxic. } & 0.920 & 0.251 & 27.3 & 0.347 & 37.6 & 0.279 & 30.3 \\
\hline 300 & & 0.978 & 0.295 & 30.2 & 0.374 & 38.2 & 0.270 & 27.6 \\
\hline 500 & & 0.962 & 0.270 & 28.0 & 0.377 & 39.2 & 0.275 & 28.6 \\
\hline & \multicolumn{8}{|c|}{ Skałki } \\
\hline- & \multirow{3}{*}{$\mathrm{pH} \sim 5$} & 0.725 & 0.140 & 19.3 & 0.322 & 44.5 & 0.241 & 33.2 \\
\hline 300 & & 0.738 & 0.148 & 20.1 & 0.343 & 46.5 & 0.236 & 32.0 \\
\hline 500 & & 0.730 & 0.142 & 19.4 & 0.339 & 46.4 & 0.231 & 31.6 \\
\hline- & \multirow{3}{*}{ anoxic } & 0.718 & 0.172 & 24.0 & 0.333 & 46.4 & 0.182 & 25.3 \\
\hline 300 & & 0.720 & 0.170 & 23.7 & 0.348 & 48.2 & 0.170 & 23.6 \\
\hline 500 & & 0.706 & 0.159 & 22.6 & 0.375 & 53.1 & 0.147 & 20.8 \\
\hline
\end{tabular}

Table 5. Monitored parameters in the solutions before and after 10 weeks of exposure in anoxic and decreased $\mathrm{pH}$ conditions

\begin{tabular}{|c|c|c|c|c|c|c|c|c|}
\hline \multirow{3}{*}{$\begin{array}{c}\text { Dosage } \\
\text { gypsum } \\
{[\mathrm{mg}]}\end{array}$} & \multirow{3}{*}{ Station } & \multirow{3}{*}{ Conditions } & \multicolumn{2}{|c|}{$\mathrm{pH}$} & \multicolumn{2}{|c|}{$\begin{array}{c}\text { Oxygen } \\
\mathrm{O}_{2}\left[\mathrm{mgO}_{2} \mathrm{dm}^{-3}\right]\end{array}$} & \multicolumn{2}{|c|}{$\begin{array}{l}\text { Potential } \\
\text { Eh [mV] }\end{array}$} \\
\hline & & & before & after & before & after & before & after \\
\hline & & & \multicolumn{2}{|c|}{10 weeks } & \multicolumn{2}{|c|}{10 weeks } & \multicolumn{2}{|c|}{10 weeks } \\
\hline- & \multirow{3}{*}{ Centralny } & \multirow{6}{*}{ anoxic } & & 7.26 & & 0.11 & & 160.5 \\
\hline 300 & & & 7.82 & 6.66 & 0.02 & 0.09 & 127.6 & - \\
\hline 500 & & & & 6.75 & & 0.12 & & 177.9 \\
\hline- & \multirow{3}{*}{ Skałki } & & & 7.41 & & 0.09 & & 159.6 \\
\hline 300 & & & 7.95 & 7.22 & 0.03 & 0.08 & 130.1 & - \\
\hline 500 & & & & 7.10 & & 0.15 & & 182.1 \\
\hline- & \multirow{3}{*}{ Centralny } & \multirow{6}{*}{$\mathrm{pH} \sim 5$} & & 5.22 & & 6.09 & - & - \\
\hline 300 & & & 5.02 & 5.26 & 7.11 & 5.94 & 521.3 & - \\
\hline 500 & & & & 5.16 & & 6.49 & - & - \\
\hline- & \multirow{3}{*}{ Skałki } & & & 5.29 & & 5.42 & - & - \\
\hline 300 & & & 4.99 & 5.14 & 7.16 & 6.06 & - & - \\
\hline 500 & & & & 5.20 & & 6.28 & - & - \\
\hline
\end{tabular}

\section{Impact of gypsum application on selected parameters of water}

Introduction of dihydrate calcium sulphate (VI) into the reservoir may cause significant increase in concentration of calcium and sulphates in the water. Not only does this bear a significance in case of using the water from the reservoir for drinking, as the aforesaid condition is also important for the industrial and farming purposes [Bartoszek 2008]. In samples with applied gypsum, calcium concentrations in solutions after 10week exposure were approx. 5-10 times higher than in test samples depending on the dose used and on place from which the deposits were drawn (Table 6). However, no significant impact of exposure conditions on concentration of calcium in water was noticed. In case of the calcium concentration value so high, it is required that water undergoes purification before becoming suitable for consumption [Dz.U. z 2015 r. poz. 1989]. Concentrations of sulphates in water in samples with gypsum were also higher than those observed in the control samples, but not as high as to make the water unsuitable for consumption. After 10-week exposure in anoxic conditions, concentrations of sulphates in solutions were often lower than after 
Table 6. Influence of gypsum application on concentrations of calcium, sulphate and iron in the solutions after 10 weeks of exposures in decreased $\mathrm{pH}$ and anoxic conditions

\begin{tabular}{|c|c|c|c|c|c|c|}
\hline \multirow{2}{*}{$\begin{array}{l}\text { Dosage } \\
\text { gypsum }\end{array}$} & \multicolumn{3}{|c|}{$\mathrm{pH} \sim 5$} & \multicolumn{3}{|c|}{ Anoxic } \\
\hline & $\mathrm{Ca}$ & $\mathrm{SO}_{4}^{2-}$ & $\mathrm{Fe}$ & $\mathrm{Ca}$ & $\mathrm{SO}_{4}^{2-}$ & $\mathrm{Fe}$ \\
\hline [mg] & \multicolumn{6}{|c|}{$\left[\mathrm{mg} \mathrm{dm}^{-3}\right]$} \\
\hline \multicolumn{7}{|c|}{ Centralny } \\
\hline- & 22.0 & 47.4 & 0.06 & 24.0 & 81.6 & 1.09 \\
\hline 300 & 125.3 & 107.1 & 0.00 & 160.3 & 99.3 & 3.16 \\
\hline 500 & 236.5 & 124.1 & 0.00 & 244.5 & 106.5 & 9.00 \\
\hline \multicolumn{7}{|c|}{ Skałki } \\
\hline- & 34.5 & 45.0 & 0.09 & 27.0 & 94.3 & 0.93 \\
\hline 300 & 170.3 & 107.7 & 0.09 & 168.3 & 115.1 & 2.65 \\
\hline 500 & 295.6 & 133.0 & 0.06 & 263.5 & 118.7 & 6.51 \\
\hline
\end{tabular}

exposure in conditions with decreased $\mathrm{pH}$, despite the fact that sodium sulphate (IV) was applied into this system in order to deoxidize the solutions.

In the samples with applied dihydrate calcium sulphate (VI), after 10-week exposure in anoxic conditions much greater release of iron from deposits to solutions than in control samples was observed (Table 6.). The higher concentration of sulphates in solutions favoured the creation of soluble compounds of $\mathrm{Fe}$ and $\mathrm{SO}_{4}{ }^{2-}$. Soluble iron (III) salts include, among other substances: $\mathrm{Fe}_{2}\left(\mathrm{SO}_{4}\right)_{3}$ as well as alum, with formula as follows: $\mathrm{FeMe}\left(\mathrm{SO}_{4}\right)_{2} \cdot 12 \mathrm{H}_{2} \mathrm{O} \quad\left(\mathrm{Me}=\mathrm{NH}_{4}^{+}, \mathrm{K}^{+}, \mathrm{Na}^{+}\right)$. Iron (II) salts include the following compounds: $\mathrm{FeSO}_{4}$ and Mohr's salt $\mathrm{Fe}\left(\mathrm{NH}_{4}\right)_{2}\left(\mathrm{SO}_{4}\right)_{2} \cdot 6 \mathrm{H}_{2} \mathrm{O}$ [Minczewski and Marczenko 2004]. In anoxic conditions, the reduction of $\mathrm{Fe}$ (III) which accompanies oxidization of the organic substances may lead to emergence of higher concentrations of Fe (II) in the water. Hydrogen sulphide, which is formed as a result of microbiological reduction of sulphates, should bond the iron (II), creating a sparingly soluble iron (II) sulphide. In conditions of natural aquatic environment, the reactions of $\mathrm{Fe}$ (III) and sulphate reduction may take place simultaneously. Competitiveness of these reactions depends on permanence of iron (III) forms as well as on the $\mathrm{pH}$ value. The sulphate content has a lesser impact on the above phenomena [Postma and Jakobsen 1996]. Hydrogen sulphide could also cause reduction of iron (III) and increase the rate its release into the solution. For iron (III) reduction to take place via $\mathrm{H}_{2} \mathrm{~S}$ an extremely high excess of hydrogen sulphide is necessary [Golterman 2001]. Black colour of the surface layer of deposits as well as intense black coating on the reactor walls above the deposit clearly indicated occurrence of strong reduction conditions inside the reactors during the 10 -week exposure, par- ticularly in samples with higher sulphate (VI) calcium dose. Creation of iron (II) sulphide has been observed.

Lesser degree of iron release was observed in the coarse-grained, partly sandy deposits from the Skałki station. The largest quantity and diversity of bacteria occurs in sandy deposits, lower - in argillaceous deposits. Rate at which mineralization occurs is much slower in argillaceous deposits than in sandy deposits [Olańczuk - Neyman 2001]. However, the research conducted in the years 2005-2006 indicated that deposits from both these sites differed significantly in terms of content of selected substances. Sediments from the Skałki station were characterized, among other features, by lower content of iron and organic matter in comparison to sediments from the Centralny station [Bartoszek et al. 2015].

In hypertrophic Laikkalammi lake, after introduction of gypsum, concentrations of sulphates in the water increased from almost 0 to approx. 150 $\mathrm{mg} \mathrm{dm}{ }^{-3}$. As a result of sulphate depletion as an electron acceptor and of sulphide creation, concentration of $\mathrm{SO}_{4}{ }^{2-}$ ion decreased to approx. 100 $\mathrm{mg} \mathrm{dm}^{-3}$ [Salonen et al. 2001]. However, neither increased iron concentration nor changes in $\mathrm{pH}$ values of the water were found.

\section{CONCLUSIONS}

In the case of high content of iron, aluminium and manganese as well as of resulting high natural phosphorus retention capacities in the sediments of the Solina Reservoir, gypsum had no impact on the process of phosphorus retention in deposits in slightly acidic environment in aerobic conditions. Apart from that, in sediments exposed in anoxic conditions, it was found no significant impact 
of gypsum on increase in phosphorus retention, which was already at a very high level in control samples. From subsequent phosphorus portion in anoxic conditions, sediment cores without second application of gypsum retained only up to $18 \%$ more of this element from the solution. The conducted research indicated that retention capacities of deposits, which become increased after the use of gypsum, will decrease over time (e.g. after winter period). Therefore, it will be necessary to repeat the application within several subsequent years, as it occurs in case of iron and aluminium compounds most commonly used to increase sorption capacities of the sediments with regards to phosphates.

The analysis of phosphorus fractionation in the sediments showed a slight increase in apatite fraction content and a slight decrease of organic phosphorus content in case of the deposits with added gypsum. However, those differences were small and irregular, they could also be caused by heterogeneity of undisturbed sediment cores in terms of phosphorus distribution.

Application of gypsum significantly increased calcium concentration in solutions, which exceeded the standard values acceptable for drinkable water. Intense release of a water-soluble form of iron from deposits to the solutions and decreased $\mathrm{SO}_{4}{ }^{2-}$ content during the 10-week exposure in anoxic conditions indicates the use of iron (III) and sulphates as electron acceptors in the process of oxidization of organic substances. More intense release of $\mathrm{Fe}$ in the presence of gypsum indicates occurrence of iron (III) reduction also with participation of $\mathrm{H}_{2} \mathrm{~S}$.

Lack of more evident effects of gypsum application is caused mainly by high natural retention capacities of deposits in the Solina Reservoir, which result from their significant content of iron, aluminium and manganese, i.e. elements that have a great influence on the increase in phosphorus retention.

\section{Acknowledgements}

Financial support was provided by the grant No. N N305 077836 from the Poland's Ministry of Science.

\section{REFERENCES}

1. Bajkiewicz-Grabowska E. 2002. Obieg materii w systemach rzeczno-jeziornych. Uniwersytet
Warszawski, Wydział Geografii i Studiów Regionalnych, Warszawa.

2. Bartoszek L. 2008. Badania retencji związków fosforu w osadach dennych na przykładzie zbiorników zaporowych Solina - Myczkowce. Dysertacja doktorska, Wydział Inżynierii Środowiska Politechniki Lubelskiej, Rzeszów.

3. Bartoszek L., Tomaszek J.A. 2010. Wpływ dwuwodnego siarczanu (VI) wapnia na retencję fosforu w osadach dennych zbiorników zaporowych Solina - Myczkowce. [In:] R. Wiśniewski (Ed.) Ochrona i rekultywacja jezior. Polskie Zrzeszenie Inżynierów i Techników Sanitarnych Oddział Toruń, 21-30.

4. Bartoszek L., Czech D. 2014. Podatność na degradację zbiornika zaporowego Solina. Czasopismo Inżynierii Lądowej, Środowiska i Architektury, 61(4), 35-53.

5. Bartoszek L., Tomaszek J.A., Lechowicz J.B. 2015. Differentiation of selected components in bottom sediments of Poland's Solina-Myczkowce complex of dam reservoirs. [In:] J.A. Tomaszek, P. Koszelnik (Eds.) Progress in the Environmental Engineering. Water, Wastewater Treatment and Environmental Protection Issues. Taylor \& Francis, London, 11-22.

6. Bartoszek L., Koszelnik P. 2016. Assessment of phosphorus retention in the bottom sediments of the Solina-Myczkowce complex of reservoirs. Rocznik Ochrona Środowiska, 18, 213-230.

7. Berg U., Neumann T., Donnert D., Nüesch R., Stüben D. 2004. Sediment capping in eutrophic lakes - efficiency of undisturbed calcite barriers to immobilize phosphorus. Applied Geochemistry, 19, 1759-1771.

8. Dz.U. 2015. poz. 1989. Rozporządzenie Ministra Zdrowia $\mathrm{Z}$ dnia 13 listopada 2015 r. W sprawie jakości wody przeznaczonej do spożycia przez ludzi.

9. Golterman H.L. 2001. Phosphate release from anoxic sediments or "What did Mortimer really write?”. Hydrobiologia, 450, 99-106.

10. Gruca-Rokosz R., Tomaszek J.A., Koszelnik P. 2009. Denitrification in the sediment of a eutrophic reservoir as measured by the isotope pairing technique. Oceanological and Hydrobiological Studies, 38(1), 75-81.

11. Gruca - Rokosz R., Tomaszek J.A., Koszelnik P., Czerwieniec E. 2011. Methane and carbon dioxide fluxes at the sediment-water interface in some reservoirs in SE Poland. Polish Journal of Environmental Studies, 20(1), 83-88.

12. Koszelnik P., Tomaszek J.A., Gruca-Rokosz R. 2002. Variations in the N:P ratio in the Solina Reservoir ecosystem during 1999-2000. Environment Protection Engineering, 28(1), 91-98. 
13. Lin Y., Singer P.C. 2006. Inhibition of calcite precipitation by orthophosphate: speciation and thermodynamic considerations. Geochimica et Cosmochimica Acta, 70, 2530-2539.

14. Lossow K., Gawrońska H. 2000. Przegląd metod rekultywacji jezior. Przegląd Komunalny, 9(108), $94-106$.

15. Liu Y., Sheng X., Dong Y., Ma Y. 2012. Removal of high-concentration phosphate by calcite: effect of sulfate and $\mathrm{pH}$. Desalination, 289, 66-71.

16. Minczewski J., Marczenko Z. 2004. Chemia analityczna. Podstawy teoretyczne i analiza jakościowa. t.1. PWN, Warszawa.

17. Olańczuk-Neyman K. 2001. Mikroorganizmy w kształtowaniu jakości i uzdatnianiu wód podziemnych. Monografie Komitetu Inżynierii Środowiska PAN, Wydawnictwo Politechniki Gdańskiej, Gdańsk.

18. Prepas E.E., Babin J., Murphy T.P., Chambers P.A., Sandland G.J., Ghadouanis A., Serediak M. 2001a. Long-term effects of successive $\mathrm{Ca}(\mathrm{OH}) 2$ and $\mathrm{CaCO} 3$ treatments on the water quality of two eutrophic hardwater lakes. Freshwater Biology, 46, 1089-1103.

19. Prepas E.E., Pinel - Alloul B., Chambers P.A., Murphy T.P., Reedyk S., Sandland G., Serediak M. 2001b. Lime treatment and its effects on the chemistry and biota of hardwater eutrophic lakes. Freshwater Biology, 46, 1049-1060.

20. Postma D., Jakobsen R. 1996. Redox zonation: Equilibrium constraints on the $\mathrm{Fe}(\mathrm{III}) / \mathrm{SO} 42--$-re- duction interface. Geochimica et Cosmochimica Acta, 60(17), 3169-3175.

21. Salonen V-P., Varjo E., Rantala P. 2001. Gypsum treatment in managing the internal phosphorus load from sapropelic sediments; experiments on Lake Laikkalammi, Finland. Boreal Environ. Res., 6, $119-129$

22. Sø H.U., Postma D., Jakobsen R., Larsen F. 2011. Sorption of phosphate onto calcite; results from batch experiments and surface complexation modeling. Geochimica et Cosmochimica Acta, 75(10), 2911-2923.

23. Wiśniewski R. 1995. Rola resuspensji osadów dennych w funkcjonowaniu ekosystemów wodnych. Rozprawy UMK, Toruń.

24. Wiśniewski R. 2006. Stan i potencjalne metody rekultywacji płytkiego, przymiejskiego jeziora Jelonek. IV Ogólnopolska Konferencja NaukowoTechniczna: Postęp w Inżynierii Środowiska, Rzeszów-Bystre k. Baligrodu, 265-274.

25. Zbierska A., Przybyła C., Dwornikowska Ż. 2016. Seasonal variability of selected nutrients in the waters of lakes Niepruszewskie, Pamiatkowskie and Strykowskie. Journal of Ecological Engineering, 17(4), 129-137.

26.Zhang Y., Ghadouani A., Prepas E.E., Pinel-Alloul B., Reedyk S., Chambers P.A., Robarts R.D., Methot G., Raik A., Holst M. 2001. Response of plankton communities to whole-lake $\mathrm{Ca}(\mathrm{OH}) 2$ and $\mathrm{CaCO} 3$ additions in eutrophic hardwater lakes. Freshwater Biology, 46, 1105-1119. 